Journal of

\title{
Education and Practice
}

(JEP) PREDICTABILITY OF INSTRUCTIONAL QUALITY ON TEACHERS AT THE COLLEGE OF DISTANCE EDUCATION UNIVERSITY OF CAPE COAST

Dr. Felix Senyametor, Dr Mark Owusu Amponsah, Banini Nutifafa and Prof. Koawo Edjah
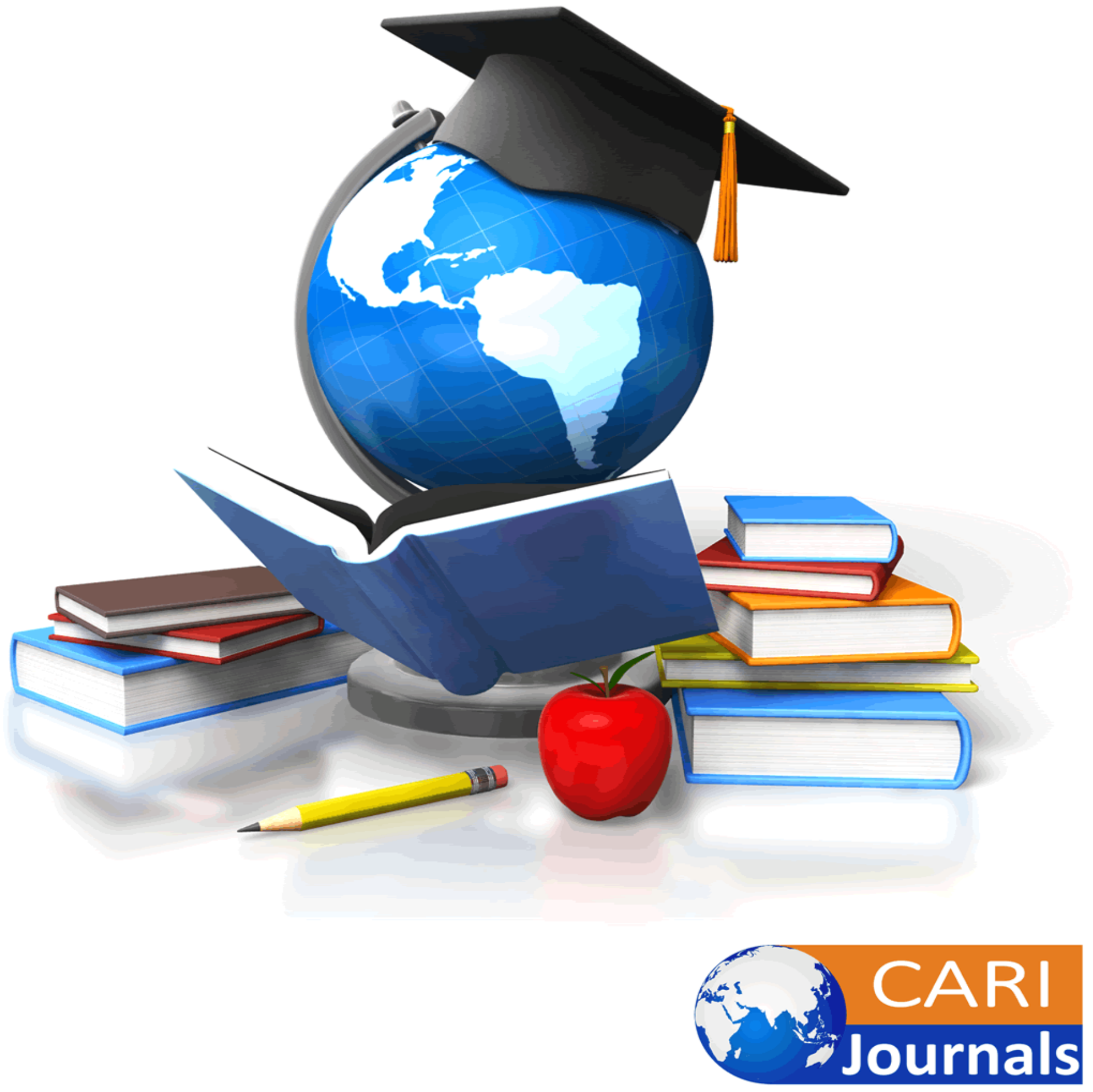


\title{
PREDICTABILITY OF INSTRUCTIONAL QUALITY ON TEACHER EFFECTIVENESS IN THE PREPARATION OF TEACHERS AT THE COLLEGE OF DISTANCE EDUCATION UNIVERSITY OF CAPE COAST
}

\author{
${ }^{1 *}$ Dr. Felix Senyametor \\ Department of Education and Psychology \\ University of Cape Coast, Ghana \\ *Corresponding Author's Email: felix.senyametor@ucc.edu.gh \\ ${ }^{2}$ Dr Mark Owusu Amponsah \\ Department of Education and Psychology \\ University of Cape Coast, Ghana \\ Corresponding Author's Email: mamponsah1@ucc.edu.gh \\ ${ }^{3}$ Banini Nutifafa \\ Department of Early Childhood Education \\ University of winneba, Ghana
}

Corresponding Author's Email:nk@@gmbanini@uew.edu.gh.com

${ }^{4}$ Prof. Koawo Edjah

Department of Education and Psychology

University of Cape Coast, Ghana

Corresponding Author's Email: kedjah@ucc.edu.gh

\begin{abstract}
Purpose: The purpose of the study was to examine the predictability of instructional quality on trainee-teacher effectiveness in the delivery of Distance Education (DE) in Ghana, focusing on College of Distance Education, University of Cape Coast (CoDE, UCC).

Methodology: The descriptive survey design was adopted with a quantitative approach. Total population involving 1,837 CoDE course tutors and all CoDE students at 76 study centres offering education programmes totaling 51,456 were used. The sample size for the study was 726, made up of 397 trainee-teachers and 329 course tutors. The proportionate stratified random sampling approach was employed to select respondents who completed the questionnaire instruments. The statistical analysis software tool known as the PASW Version 21.0, the Test Analysis for Surveys (TAFS) was used for analysing the data. Data on the research question was analysed using linear multiple regression analysis.

Findings: The results revealed that pedagogical quality and quality evaluation were the dimensions of instructional quality that most significantly predicted trainee-teacher effectiveness.
\end{abstract}


Journal of Education and Practice

ISSN 2520-467X (Online)

Vol.4, Issue No.2, pp $1-19,2020$

www.carijournals.org

Again, whenever trainee-teachers demonstrate high level of competence in terms of subject matter knowledge, lesson presentation skills, class management and control and lesson note preparation, they increase the extent to which their level of teaching meets pre-specified standards and goals of the college.

Unique contribution to theory, practice and policy: It was recommended that management of CoDE, UCC should put in place appropriate support services in all the study centres to guide both tutors and students on appropriate instructional behaviour.

Keywords: Distance education, Instructional quality, Trainee-teacher effectiveness, Course tutors.

\subsection{INTRODUCTION}

Generally, there is no common accepted definition for quality in Distance Learning (DL). This is because quality is evaluated at different levels and contexts. According to Edna and Kim (2005), the definition of quality in DL changes depending upon the level, time and context within which quality is being measured and/or addressed. Buzdar and Ali (2013), define quality as meeting accreditation standards. Hanson (2013), on the other hand defines quality as utilising tools such as interaction, self-examination, and student evaluations. Quality can also be seen as effective and appropriate instruction that focuses on the individual learner (Emmer \& Stough, 2015). Quality instruction in the context of this study therefore, refers to the availability of what is expected as teaching according to the unvaried established standards of UCC, desired standard of teaching, adequate number and level of teaching per week.

Instructional quality has become an indispensable component in the educational landscape such that no education policy or programme can do away with it. Instructional quality is achieved by measuring its positive influence on student learning outcomes (Rahman, Jumani, Akhter, Chisthi \& Ajmal, 2011). In most cases, emphasis is on the quality level of instruction with regard to pedagogical skills, teacher qualification, infrastructure, student-teacher interaction, evaluation, student support services, and teacher support services (Perez, 2013; Ogunleye, 2013). Value added studies, measuring student achievement levels that are matched with individual teachers over a number of years, have suggested that there are significant differences in teacher effectiveness for improving student learning. The evidence for this, however, is not unanimous (Bird, 2017).

Teacher effectiveness on the part of the trainee-teacher refers to the extent to which trainee-teacher effectiveness level of teaching achieves or meets pre-specified standards and goals. It is residual, additive and cumulative (Abderahman, 2012). How teacher effectiveness levels are measured and understood, and by inference how quality instruction is identified, is obscure. This is because quality instruction as a concept lacks clarity, in that quality itself is stakeholder relative (HelmsLorenz, Slof, Vermue \& Canrinus, 2017). For example, students, teachers, parents, leaders and the wider community may have differing views on quality instruction (Rowe, 2003). In addition, definitions can vary from excellence in teaching, value for public purse (Hill \& Hawk, 2017), attaining a particular purpose or simply its transformative power (Helms-Lorenz et al., 2017). Despite these variations, quality instruction is understood as student centred and its purpose is for high quality student learning outcomes, both social and academic (Albemarle, 2015). Using these studies and measures, teacher effectiveness is not marked by a set of criteria or teaching standards, 
Journal of Education and Practice

ISSN 2520-467X (Online)

Vol.4, Issue No.2, pp 1 - 19, 2020

www.carijournals.org

but measured or judged according to achievement levels in students over a number of years (Helms-Lorenz et al., 2017).

As a response to the public concern surrounding education, most countries including Ghana, have redefined the requirements that are intended to ensure quality education for all students. One of such areas of definition included in most policy documents aimed at teacher qualifications and instructional quality (Yai \& Wang, 2012). Societies require all students to be taught by highly qualified teachers. That is, teachers with professional qualifications who are able to demonstrate subject-matter competence for the courses they teach. In order to produce such teachers, there is the need to ensure that there is quality instruction in the various institutions that produce professional teachers (Antoniou \& Kyriakides, 2013).

Research has shown that the teacher is the most important school-related variable in student achievement (Wilson \& Floden, 2013; Wenglinsky, 2014). Therefore, ensuring that there is high level of instructional quality among trainee-teachers is a key pillar in producing effective teachers. The question of whether trainee-teacher effectiveness differs dramatically with regard to work output is fundamental to educational research (Wenglinsky, 2014). Implications of this research are important for educational policy and practice. It can inform what characteristics are necessary for training, certifying, and hiring effective teachers to have the greatest impact on student achievement. Although there is consensus that qualified teachers with high level of effectiveness are essential among policy makers, educational leaders, and researchers, there is little consensus about what characteristics a highly qualified effective teacher possesses. Most of the qualities that the trainee-teacher possesses can be assessed during teaching practice. The instructional quality of a teacher largely influences his/her effectiveness positively (Wang and Walberg, 2012).

\subsection{Input factors that affect trainee-teachers' level of effectiveness}

The review on instructional quality and teacher effectiveness shows that trainee-teacher effectiveness is predicted by many variables such as pedagogical quality, quality interaction classroom management, quality evaluation, and quality infrastructure and quality faculty (Mbwesa, 2014). The first to consider is pedagogical quality which comprises many dimensions including teaching methods, lesson preparation, time management, and classroom management. Teaching-learning process requires appropriate approaches of teaching (Chen, 2008; Ertmer, 2015). In this aspect, teachers have to know which strategy is better for students' learning and when. It is found in many studies that proper learning seems hard to take place following a single method of teaching. Besides, many factors are involved in effective teaching strategies such as teacher knowledge and qualification, motivation, commitment, provision for resources and use, and learning environment (Shah \& Alam, 2012).

Apart from these factors, teaching methods consist of guiding and scaffolding, direct teaching with learning materials and pupils' engagements in dialogues and class tasks. An effective teaching strategy may mean practicing and asking one another questions and repeating them in class. Effective teaching method should create room for the teacher to ignite pupils' initiatives in order to help them work together so that they can willingly help one another and can take responsible roles (Blazar, 2016).

In relation to the aspects of teacher lesson preparation, O’Neill (as cited in Yai \& Wang, 2012) in a study on the impact of teacher self-efficacy on student learning outcomes in the University of 
Journal of Education and Practice

ISSN 2520-467X (Online)

Vol.4, Issue No.2, pp 1 - 19, 2020

www.carijournals.org

Hungkang, Taiwan argued that the teaching process is divided into three stages. These are the teaching preparatory stage, teaching implementation stage and the teaching evaluation stage. All these stages help in enhancing the pedagogical quality of the teachers' instruction. According to Yai and Wang (2012), at the preparatory stage which comprises course plan and teaching preparation, the teacher ensures that the professional documents such as schemes of work, lesson plans, lesson notes and instructional materials are in place before entering into the teaching implementation stage which comprises of the teaching methods, teaching materials and classroom management. The teacher will be deemed efficient if lesson preparation enhances quality teaching and maximum learning achievement (Azkiyah, 2013).

In addition, the trainee-teacher can ensure high level of pedagogical quality when he/she ensures that there is high level of planning and preparation. This domain has several components that describe how a teacher organizes the content that students are to learn, that is, how a teacher designs instruction. Components include a deep understanding of content, pedagogy, appreciation of the students and what they bring with them (Ali, 2000). The content must be transformed through instructional design into sequences of activities and exercises accessible to the students. Muijs, Armstrong and Chapman (2010) further add that the area of lesson preparation also covers assessment plans. Assessment techniques must reflect instructional outcomes and document student progress. Assessment must be used for formative purposes and provide diagnostic opportunities for students to demonstrate their level of understanding. This domain is based on the principle that a teacher's role is not so much to teach as it is to arrange for learning. The plan and the students' assignments may be included in a teachers' profession portfolio. The plan's effects must be observed through action in the classroom and are reflected in student learning outcomes. The trainee-teacher time management on student learning can also boost the pedagogical quality of the teachers' instructional quality. Woods and Montagno (as cited in Muijs \& Reynolds, 2011) note that the teacher-student interaction is very crucial for meaningful learning, however, this interaction is occasionally affected by student-teacher contact hours lost through teacher absenteeism. This means that the planned teaching-learning time is wasted; thus denying students an opportunity to have meaningful learning. In developing countries, Abdus-Salam (2015) argues that schools often offer to the students only a fraction of the time that the government plans and pays for; hence, not making best use of teachers.

The next dimension to consider is teacher classroom management. Classroom can be organized in different ways to support learners. In this context, Walters (2002) says that whole class approach facilitates to disseminate the same information to the whole class and to assess pupils where the members of a group can cooperate and support each other to do their tasks in different ways. However, classrooms should be organized in a way where teacher, group and members of groups can exchange their teaching roles. Rivkin, Hanushek and Kain (2012) suggested effective monitoring and supervision to improve communication and to ensure consistency among students for the purpose of better classroom management. In most developing countries such as Ghana, most of the conventional classes result in overcrowding during teaching-learning which brings less interaction between teacher and students. Teachers typically ask a series of pre-planned questions, initiate all the topics, and rarely interact with the substance of pupils' answers except to evaluate them. 'Real discussion' hardly happens. There is virtually no student-to-student interaction or evidence of student self-reliance or students being encouraged to generate their own questions or 
Journal of Education and Practice

ISSN 2520-467X (Online)

Vol.4, Issue No.2, pp 1 - 19, 2020

www.carijournals.org

forming of some tentative hypotheses in such classrooms. Classroom organization is also related with class size namely teacher-students ratio, teaching aids used during lesson. According to Rivkin, Hanushek and Kain (2015), teachers' pre-plans before delivering are greatly influenced by various challenges like over enrolment, teacher-students ratio and lack of adequate teachinglearning instruments. So, it is apparent that the whole class approach facilitates learners to benefit from one another through mutual interaction at the teaching venue.

Classroom management is concerned with a set of teachers' behaviour and activities that are primarily intended to foster students' co-operation in the classroom. An effective teacher is one who knows how to handle the students in class for maximum learning of students and hence the need to possess certain information and skills. In most cases, teachers in developing world use discipline to control their class. Discipline ensures how students behave when the teacher is teaching. A classroom that is not well-organized results in indiscipline problems and the teacher spends most of the teaching-learning time handling these problems rendering the teacher ineffective (Purdy, 2017). This means that a trainee-teacher who has a classroom management action plan will have an organized and structured classroom where both he/she and the students will know what to do. This trainee-teacher interaction produces good results. This is because students take responsibility and ownership for the task to be done. This shows that positive classroom environments are ones that maximize learning for all students.

Furthermore, assessment (lesson evaluation) is an integral part of teaching-learning process which facilitates solving existing problems of learners. It is a social practice that involves noticing, representing, and responding to children's literate behaviour, rendering them meaningful for particular purposes and audiences (Odden, Borman \& Fermanich, 2004). Nicole (2012) points out some ways of dynamic assessment through revision of contents and pupils' activities on their learning sheets, test and homework in order to get ideas about students and their educational needs and also to assess teacher's work to make further decisions. Though dynamic assessment considers learners as centre of learning, it is practically hard to assess all students individually in overcrowded classes (Blazar, 2016; Harris, Ingle \& Rutledge, 2014). With regard to feedback, learning outcomes are accounted as pointers whether the conducted lessons are enough for learners or not.

However, feedback should be adapted to learners' needs so that teachers can easily assess their knowledge, skills, learning potentials and needs. Feedback might be less effective in spite of having few learning outcomes of some lessons. It was found in a study conducted by Ackers and Hardman (as cited in Ogunleye, 2013) found that teachers gave feedback to students in the form of affirmation or making no reaction to pupils' responses and then went to do something else. Although they often verbally praise students' performance, they should demonstrate interests, care for their pupil's emotions, concerns and the classroom condition. After all, teachers should give chances to students to express their feelings. In this aspect, teachers can admire students verbally when satisfied with their performances. This kind of feedback is opposed by Ackers and Hardman (as cited in Ogunleye, 2013) as it discourages pupils from contributing during classroom lesson. After all, to justify students' performance, formative assessment seems more effective than verbal evaluation during teaching-learning practice in classes (Harris et al., 2014).

In relation to learning environment, Muijs and Reynolds (2000), posit that the classroom environment established by the teacher has a major impact on pupil's motivation and attitude 
Journal of Education and Practice

ISSN 2520-467X (Online)

Vol.4, Issue No.2, pp $1-19,2020$

$\underline{\text { www.carijournals.org }}$

towards learning. In this respect, purposeful, task oriented and supportive classrooms generally facilitate students' learning. In addition, a safe and open environment facilitates shared norms and values; makes students listen to understand; participate fully; respect others and their ideas. In order to make lesson flexible, teachers can follow time schedule to meet pupils' interests for work and their educational needs. Along with classroom setting, school environment contributes to the success or failure of learners in their reading performance (Lee, 2015). Besides, quality learning is also concerned with home environment. As Koomson, Brown, Anyagre, Ahiatrogah and Dawson-Brew (2017) argue, learning competencies depend on positive interactions with school and home environment. Therefore, well-organized classes concerned with home and school environment would facilitate generate knowledge for learners from both home and school.

The next dimension to consider is infrastructure quality and teaching aids. Quality of classroom interaction might be hampered due to insufficient teaching resources and poor physical facilities. Different teaching materials such as textbooks, pen, pencil, cards, big papers, building blocks, straws, wooden chips, money, body and social games can be employed during lessons. Even different objects like teaching sheets can be used as medium of instruction in order to meet pupils' needs. In general, teachers apply different contents supplied by the educational authorities. Likewise, they adopt teaching plans based on classroom conditions. Inadequacy of materials by and large hampers teaching and learning process in classroom (Feldman, 2013; Kizilbash, 2014).

Another important factor that influences instructional quality of the trainee-teacher is faculty quality. All students deserve a teacher who can help them to be independent learners. Grasha and Yangarber-Hicks (2013) suggest that teachers develop and improve their instructions through inquiry in order to positively influence student learning. Besides, teachers could also experience learning by examining student thinking, co-planning, co-teaching, and other forms of assistance in class (Khan \& Halai, 2014). So experience plays an important role to bring effectiveness to teaching because expert teachers are thought to know effective ways of dealing with learners compared to less experience ones (Dillon \& Blanchard, 2015; Grasha, 2016). This shows that teachers could properly utilize their knowledge and practice norms and standards based on their professional experiences in spite of having inadequate teaching-learning resources. They could even enrich assessment procedures, maintain assessment tasks and collect learners' portfolios and achievements.

Along with this, trainee-teachers must be apt to resolve different challenges during teaching. Accordingly, they have to know how to manage difficult situations amongst a group of peoples in order to help them to learn now, and to become better learners in future. Besides, trainee-teachers should be adept at monitoring pupils' progress and to identify learners' weaknesses so that they could adapt their strategies to meet their needs. In this context, teacher's knowledge, roles, skills, dispositions, and behaviours, all have great influence on effective teaching (Darling-Hammond, 2014). Indeed, teachers who exhibit high level of instructional quality know how to create successful learning environment in classroom. Therefore, an effective teacher must be an expert in the subject matter as well as action based pedagogical knowledge, have mastery in the language of instruction, create productive and joyful learning environment, arouse interests among the students in their studies, generating compliant classroom environment for students' needs, bearing strong ethical minds, dedication in profession and intensive caring for students (Ertmer, 2015; Harris \& Sass, 2017). 
Journal of Education and Practice

ISSN 2520-467X (Online)

Vol.4, Issue No.2, pp $1-19,2020$

www.carijournals.org

\subsection{Conceptual framework based on instructional quality}

According to Mbwesa (2014), assessment of instruction in distance education cannot be done without consideration to quality standards and variables established to guide instruction in higher education. As a result, Mbwesa (2014) outlined 10 quality dimensions which influenced us in adapting part of her instructional quality dimensions for this study. The dimensions were faculty support, student support, interactive tasks, pedagogical, evaluation and assessment, infrastructure, institutional quality assurance mechanism, institutional credibility and accreditation, course development, and information and publicity dimension. Based on the ideas that emerged from the review of related multiple theories and the empirical works, the researchers were able to conceptualise the argument of the study into coherent model. In other words, the conceptual framework for this study took into consideration all the possible factors from the literature and from observations to derive the dependent, independent, and gender variables. The dependent variable was trainee-teacher effectiveness while the five dimensions of instructional quality (See Figure 1) constitute the independent variables.

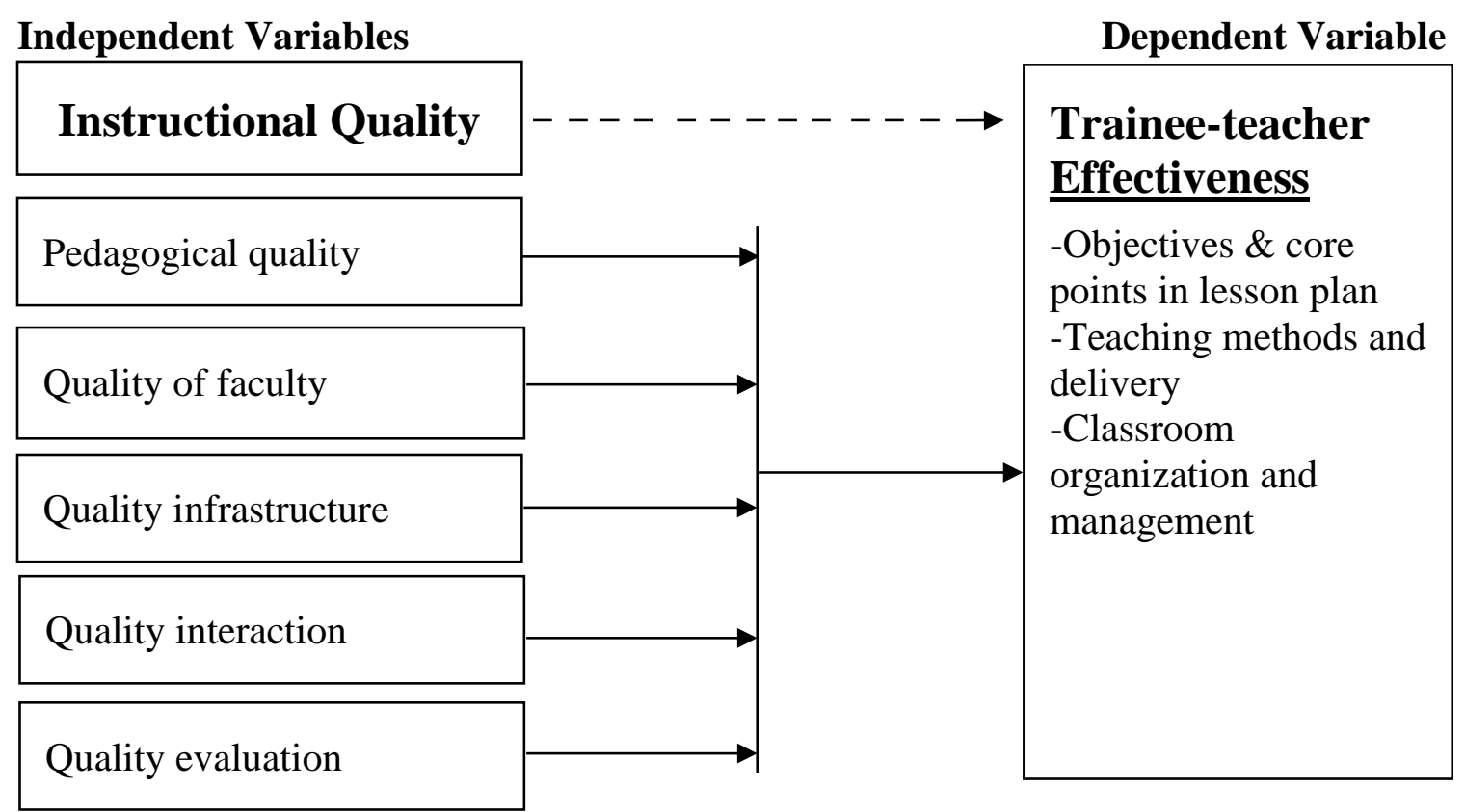

\section{Figure 1: Conceptual Model on the Predictability of Instructional Quality on Trainee- Teacher effectiveness.}

We are of the view that distance learners of CoDE, UCC consider the five dimensions of instructional quality depicted in Figure 1 as those that really defined DL instruction. Quality teaching or instruction does not exist independent of quality learning and application or transfer of learning to practical situations. To ensure high level of instructional quality on the part of traineeteachers, there is the need to develop and implement a system for high-quality teaching that is predicated on curricula, assessment, and instruction as they facilitate all learners' attainment of deep understanding of the disciplines and concepts. When students explore concepts over time as opposed to facts in isolation, they develop deeper understanding and are able to transfer knowledge across disciplines and situations. 
Journal of Education and Practice

ISSN 2520-467X (Online)

Vol.4, Issue No.2, pp $1-19,2020$

www.carijournals.org

As presented in Figure 1, the argument of the study is that trainee-teachers benefiting from instructional quality dimensions influence their effectiveness positively. This means that when course facilitators are able to use appropriate instructional methods that promote learner interactions during their On Centre Teaching Practice (OCTP) as well as deliver suitable and quality content to learners, they will be able to meet the expected unvaried teaching standards established by UCC. These include desired standard of teaching, adequate number and level of teaching per week. These dimensions to a large extent will positively predict trainee-teachers' level of effectiveness in teaching that meets pre-specified standards and goals. It will also boost traineeteachers' belief in their personal ability to execute the courses of action needed to positively affect student performance.

Therefore, if the course facilitators'/tutors instructional quality dimensions are viewed in positive terms or are in good shape, they will be in a better position to put in some level of effort in their teaching and supervision of OCTP which will strengthen their learners teaching skills and in the long run to boost their effectiveness. Trainee-teachers believing that they can perform well in the programme with some level of effort in their instructional practices will significantly increase their effectiveness in the teaching profession.

\subsection{Statement of the problem}

UCC has succeeded immensely in fulfilling its mandate in the training of thousands of teachers and even other professionals in business and commerce to man the various sectors of the Ghanaian economy. However, an area of concern, through experience and observation, which needs to be addressed in the University, has to do with the quality dimension of instruction in terms of quality pedagogical approach, lesson assessment and evaluation. These challenges need to be addressed to enhance the relevance and competitiveness of the university's Distance Learning (DL) locally and internationally. Other researchers have also posited that the most significant factors that institutions providing DL are facing are instructional quality and trainees' effectiveness (Alharbi, 2017; Badu-Nyarko, 2010; Dankyi, 2016; Hannay \& Newvine, 2016; Owusu-Boateng \& Essel, 2011). According to Hannay and Newvine (2016), these challenges culminate into the negative perception that stakeholders are having towards DL graduates.

These challenges are not different from those identified by Mbwesa (2014) which pertain to the quality of instruction, faculty quality, pedagogical quality and quality assurance mechanisms. Others are poor infrastructural quality, poor quality of facilitators' evaluation of trainee-teacher effectiveness and limited use of technology in the delivery of services and instruction (Alharbi, 2017; Dankyi, 2016; Hannay \& Newvine, 2016). These challenges are likely to have telling effects on trainee-teacher effectiveness. CoDE (2016) monitoring and evaluation survey report revealed that about 30 percent of Senior High School (SHS) graduates pursuing CoDE education programmes from seven regions of the country without any initial teacher training from Colleges of Education and were not already practicing as non-professional teachers in the classroom had challenges with professional preparation of lesson notes. This is an indication of low teacher effectiveness. An effective teacher is the one who gets things done in the right and most effective ways in terms of class management, time management, professional preparation of lesson plans, instructional materials, engagement of time on task, and getting things organized in order to enhance the output or results of learners in the teaching-learning process (Alharbi, 2017). An effective teacher, therefore, is rich in both subject matter and action system knowledge in terms of 
Journal of Education and Practice

ISSN 2520-467X (Online)

Vol.4, Issue No.2, pp $1-19,2020$

$\underline{\text { www.carijournals.org }}$

pedagogical competence, statement of instructional objectives, lesson introduction, and development of teacher-learner activity, lesson closure and evaluation.

There have been some studies in DL about the effects of Distance Education (DE) on teacher performance (Dankyi, 2013), DL our hope for a sustained human capacity development in Ghana (Anamuah-Mensah, 2015), and as a strategy for training teachers in Ghana with regard to its problems and prospects (Koomson, 2007). Other studies also touched on the perceived effects of DL on teacher performance (Kwakyewaa, 2013), study habit among UCC distance learners (Ahiatrogah, Deku \& Bakari, 2008: Dankyi, 2013) and conceptual model on interactivity for effective distance learning in higher education (Farajollahi, Zare, Hormozi, Sarmadi, Zarifsanaee, 2010). Unfortunately, it appears that there has not been any scientific study in existing literature in Ghana on quality dimension of instruction on DL in general and UCC in particular. It is to fill this void in research that this study was carried out.

\subsection{Purpose of the study}

The purpose of this study was to examine the predictability of instructional quality on teacher effectiveness in the preparation of teachers at the College of Distance Education, University of Cape Coast.

\subsection{Research questions}

To what extent do the dimensions of instructional quality predict trainee-teacher effectiveness in the preparation of teachers in distance education at CoDE, UCC?

\subsection{METHODOLOGY}

\subsection{Research Design}

The descriptive design was adopted in for the study. This design was employed in gathering data about the respondents in order to answer research questions concerning the current status of examining the predictability of instructional quality on trainee teacher effectiveness in distance education at the University of Cape Coast.The descriptive survey design guided the research activity and also ensured that sound conclusions were reached. Even though the design of the study was descriptive survey, the nature of the study was cross sectional.

\subsection{Population}

The study population was all CoDE course tutors, totalling 1837 made up of 1,051 males and 786 females and all CoDE students at all the 76 study centres offering education programmes across three stratified zones of Ghana (Southern, Middle and Northern) totalling 51,456 made up of 29,126 males and 22,330 females (CoDE, UCC, 2017a). The population for the study therefore, was 53,293.

\subsection{Sample and sampling procedure}

A sample size of 726 was obtained using Galero-Tejero (as cited in White, 2015) and used for the study. The sample comprised of 397 trainee-teachers and 329 course tutors. Thus, using a population size of 53,293, a sample of 726 was obtained. The 726 sampled was made up of 397 trainee-teachers and 329 course tutors. The lottery method of simple random sampling technique was first employed to select one region from each of the three Zones. In all, three regions were 
Journal of Education and Practice

ISSN 2520-467X (Online)

Vol.4, Issue No.2, pp $1-19,2020$

$\underline{\text { www.carijournals.org }}$

selected from all the zones. These were Greater-Accra, Ashanti and Northern Regions. All the 34 study centres in these selected regions that run education programmes were used for the study. Since the total population sizes of course tutors and trainee-teachers in the selected three regions were 697 and 21,312 respectively, the proportional sampling procedure was used to allocate 47.2 percent for course tutors and 1.9 percent for trainee-teachers with regard to gender stratum (see Table 1). This was done to ensure that there is fair and equitable distribution of the elements to the various strata. Purposively, the study selected only trainee-teachers who have been scheduled to do On-Centre Teaching Practices at the various study centre

Table 1: Distribution of the Sample

\begin{tabular}{|c|c|c|c|c|c|c|c|}
\hline \multirow[b]{2}{*}{ Zones } & \multirow[b]{2}{*}{ Regions } & \multirow[b]{2}{*}{ Study Centres } & \multicolumn{2}{|c|}{ Course Tutors } & \multicolumn{2}{|c|}{ Students } & \multirow[b]{2}{*}{ Total } \\
\hline & & & Male & Female & Male & Female & \\
\hline $\begin{array}{l}\text { Southe } \\
\text { rn } \\
\text { zone }\end{array}$ & $\begin{array}{l}\text { Greater- } \\
\text { Accra }\end{array}$ & $\begin{array}{l}\text { Tema SHS; Papafio Hills; } \\
\text { Odorgonno SHS; Zenith } \\
\text { College; St. Margaret Mary; Ada } \\
\text { College of Edu.; WASS, Adenta; } \\
\text { Tema Parents; Fafraha Comm. } \\
\text { SHS; Tema Datus; Ebenezer } \\
\text { SHS, }\end{array}$ & 56 & 42 & 60 & 46 & 204 \\
\hline $\begin{array}{l}\text { Middl } \\
\text { e zone }\end{array}$ & Ashanti & $\begin{array}{l}\text { KSTS; Simms SHS; Kumasi } \\
\text { Anglican SHS; WESCO; } \\
\text { Mmofraturo SHS; Kumasi Poly; } \\
\text { Serwaa Nyako SHS; T.I } \\
\text { AMASS; Konongo Odumase } \\
\text { SHTS; Obuasi SHTS; Asante } \\
\text { Mampong College; Dwamena } \\
\text { Akenten SHS; Offinso SHS; } \\
\text { SIMMS SHS; Nkawie SHS; } \\
\text { K.T.I; Mansoman SHS }\end{array}$ & 102 & 76 & 139 & 95 & 412 \\
\hline
\end{tabular}

Northe Tamale College of Edu.; Tamale

rn Poly; Gambaga Girls; Salagga

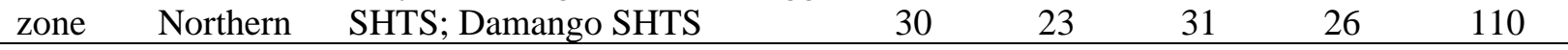


Journal of Education and Practice

ISSN 2520-467X (Online)

Vol.4, Issue No.2, pp 1 - 19, 2020

$\underline{\text { www.carijournals.org }}$

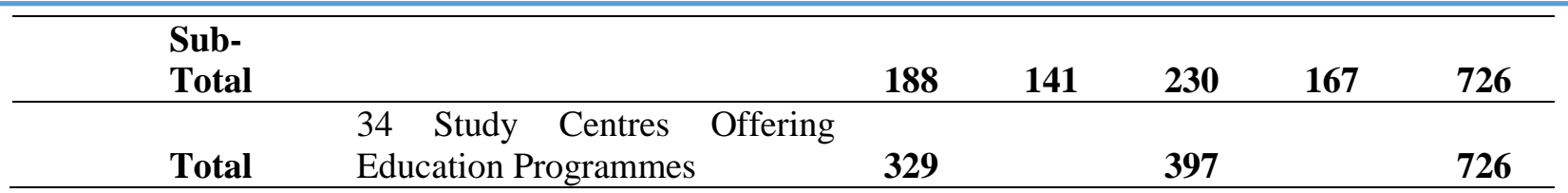

\subsection{Data collection instruments}

Questionnaires were the instruments used for the data collection. The questionnaires were designed for the selected trainee-teachers and course tutors respectively. Student Evaluation of Quality Instruction (SEQI) in Distance Education (DE) dimensions developed by Mbwesa (2014) was adapted and used. Mbwesa (2014) developed the instructional quality measurement scale based on quality dimensions created by Jung (2012) for quality DE and course facilitation. In all, 38 closeended items were used to collect data on instructional quality. Responses to the items were measured numerically using unilinear scale such that the higher the number the more one agrees with the statements and the lower the number the more one disagrees with the statements.

The course tutors' questionnaire was constructed based on the CoDE, UCC Trainee-teacher form 'A' for course facilitators to assess trainee-teachers' effectiveness for analysis. The tutors' questionnaire was used to elicit data on trainee-teachers effectiveness. Items used in this section were adapted from the TEA form ' $A$ ' which was used by them to collect data on trainees' effectiveness for the study. Trainee-teacher effectiveness scale was made up of three major sections: Objectives and core points in lesson plan, teaching methodology and delivery, and classroom organisation and management. A total of 23 close-ended items were used to elicit data on trainee-teacher effectiveness which were measured on a four-point unilinear scale.

\subsection{Data collection procedure}

Data was collected using questionnaires designed for trainee-teachers and course facilitator (tutors). Course tutors, centre and regional coordinators helped in the administering of the questionnaires. After completion of the questionnaires by trainee-teachers in each study centre, they were asked to hand over the completed questionnaire to their respective assigned assessors for On-Centre Teaching Practice. The course tutors' questionnaire had the trainee-teacher effectiveness items which they were to use in assessing each of the trainee-teachers assigned to them during the On-Centre Teaching Practice. This process created room for most of the course tutors to answer more than one course tutor questionnaire since more than one of the traineeteachers assigned to them were selected for the study.

Specifically, the respondents were identified through the sampling frame constructed using their index numbers. The questionnaire was administered to the respondents randomly after selecting them using the computer generated random number table. Contacts (phone numbers) of respondents who were not able to answer the questionnaire on the same day were taken and asked to submit the answered questionnaire on some other day. The administering process continued until all the selected respondents were captured for the study. In the case of the course tutors, the combined instruments were given to them individually outside the lecture rooms. Only assessors (course tutors) whose students were selected was considered. They answered their questionnaire during the On-Centre Teaching Practice, since they needed to see the trainee-teacher teaching in order to evaluate their effectiveness. 
Journal of Education and Practice

ISSN 2520-467X (Online)

Vol.4, Issue No.2, pp $1-19,2020$

www.carijournals.org

The data collection processes were done from one region to another and from one study centre to another. The completed combined questionnaires were collected back within a two-month period. At the end of data collection, the researcher was able to collect 374 combined, completed and accurate questionnaires. These combined questionnaires were obtained from 374 trainee-teachers and 247 course tutors. This resulted in 94.2 percent and 75.1 percent response rate with regard to the trainee-teachers and course tutors respectively.

\subsection{Data processing and analysis}

The statistical analysis software tool known as the PASW Version 21.0, the Test Analysis for Surveys (TAFS) was used for analysing the data. Data on the research question was analysed using linear multiple regression analysis. This inferential statistical tool was used to determine if the explanatory variables (components of instructional quality) explain a substantial proportion of the variance in trainee-teacher effectiveness.

\subsection{RESULTS AND DISCUSSION}

\subsection{Research Question One: To what extent do the dimensions of instructional quality predict trainee-teacher effectiveness in the preparation of teachers in distance education at CoDE, UCC?}

This question of the study was to examine how instructional quality predicts trainee-teachers' effectiveness. The independent variables were the five dimensions of instructional quality while the dependent variable was trainee-teachers' effectiveness. As indicated earlier, multiple items were used to elicit data on the independent and dependent variables. The facets or dimensions of the independent variables have also been explained earlier.

Using the linear multiple regression analysis to answer the research question, a diagnostic test was first conducted to check for multicollinearity among the independent and mediating variables. This was used to examine the possible undesirable situation where the correlations among the variables are strong. The PASW Version 21.0 was used to assess the Variance Inflation Factor (VIF) that measures multicollinearity in the regression model. All the VIF values for the independent variables were within the acceptable threshold. This shows that none of the values was greater than five (5), which means there was no collinearity associated with the variables. In all, it is clear that the contribution of the independent variables on the dependent variable was largely not as a result of the strong association among the variables. The results of the analysis are presented in Tables 2. 
Journal of Education and Practice

ISSN 2520-467X (Online)

Vol.4, Issue No.2, pp $1-19,2020$

$\underline{\text { www.carijournals.org }}$

\subsection{Results on the Predictability of Instructional Quality on Trainee-teaches' effectiveness}

Table 2: Regression Model on the Predictability of Instructional Quality on Trainee-teaches' Effectiveness

\begin{tabular}{|c|c|c|c|c|c|c|c|}
\hline \multirow[b]{2}{*}{ Variables } & \multicolumn{3}{|c|}{$\begin{array}{cc}\text { Unstandardized } & \text { Standardized } \\
\text { Coefficients } & \text { Coefficients } \\
\text { Std. } & \end{array}$} & \multirow[b]{2}{*}{$\mathbf{t}$} & \multirow[b]{2}{*}{ Sig. } & \multicolumn{2}{|c|}{ Collinearity Statistics } \\
\hline & $\boldsymbol{\beta}$ & $\begin{array}{l}\text { Std. } \\
\text { Error }\end{array}$ & Beta $(\beta)$ & & & Tolerance & VIF \\
\hline $\begin{array}{l}\text { Quality } \\
\text { infrastructure }\end{array}$ & 0.202 & 0.028 & 0.239 & 7.213 & 0.000 & .618 & 1.619 \\
\hline $\begin{array}{l}\text { Quality of } \\
\text { faculty }\end{array}$ & 0.013 & 0.030 & 0.017 & 0.426 & 0.670 & .451 & 2.218 \\
\hline $\begin{array}{l}\text { Quality } \\
\text { interaction }\end{array}$ & 0.021 & 0.029 & 0.024 & 0.701 & 0.484 & .568 & 1.760 \\
\hline $\begin{array}{l}\text { Quality } \\
\text { evaluation }\end{array}$ & 0.189 & 0.026 & 0.286 & 7.179 & 0.000 & .427 & 2.344 \\
\hline $\begin{array}{l}\text { Pedagogical } \\
\text { quality }\end{array}$ & 0.434 & 0.025 & 0.507 & 17.136 & 0.000 & .776 & 1.288 \\
\hline $\begin{array}{l}\text { Constant } \\
\mathrm{R} \\
\text { R Square } \\
\text { Adjusted R } \\
\text { Square }\end{array}$ & & & $\begin{array}{l}0.311 \\
0.867 \\
0.752 \\
0.747\end{array}$ & & & & \\
\hline
\end{tabular}

As depicted in Table 2, the instructional quality dimensions that predicted trainee-teachers' effectiveness significantly in order of importance were pedagogical quality $[(\beta=0.507(0.025), p$ $<0.01]$, quality evaluation $[\beta=0.286(0.026), \mathrm{p}<0.01]$, and Quality of faculty $[\beta=0.017(0.030)$, $\mathrm{p}<0.01]$, and quality interaction $[\beta=0.024(0.029), \mathrm{p}<0.01]$, and quality infrastructure $[\beta=$ 0.239 (0.028), $\mathrm{p}<0.01$ ]were not able to predict trainee-teachers' effectiveness significantly.

\subsection{Discussion of Results on the Predictability of Instructional Quality on Trainee-teacher effectiveness}

The results in Table 2 show that pedagogical quality, quality evaluation and quality infrastructure are the components of instructional quality that have significant impact on trainee-teachers' effectiveness. The finding is consistent with the comments of Wang and Walberg (2012), who posit that trainees with high level of instructional quality are able to demonstrate high level of effectiveness with regard to objectives and core points in lesson plan, teaching methodology and delivery, and classroom organisation and management. Teachers with high level of instructional quality are known for always coming to class (and leave) on time, with well-prepared lesson plan, instructional materials, engaged time on task, and everything is organised regardless of output or result produced in the teaching-learning process (Abdus-Salam, 2015; Wanjala \& Wanjala, 2017). 
Journal of Education and Practice

ISSN 2520-467X (Online)

Vol.4, Issue No.2, pp $1-19,2020$

www.carijournals.org

The finding that quality instruction on the part of distance learners help boost their effectiveness as trainee-teachers is consistent with that of Kwao (2002), who also found that teachers who exhibit high level of instructional quality in their lesson note preparation, pedagogical skills, quality interaction, discipline, and so on are able to enhance their competence level which in the long run help boost their students' academic performance. The consistency in the findings, with regard to this study and that of Kwao (2002), whose study focused on teachers in the conventional system, support the argument of the equivalency theory.

The equivalency theory states that for distance education to be successful it should be based on the idea of equivalency. The theory itself states that the more equivalent the learning experiences of distant learners are to those in the traditional or conventional system, the more equivalent will be the quality of products as compared to their conventional counterparts (Simonson, 1999). Therefore, education at a distance away from the traditional or convention systems of higher education should be built on the concept of equivalency of learning experiences. This approach to distance education thus advocates designing a collection of equivalent learning experiences for distant and local learners, even though they are in different worlds and contexts.

Therefore, same learning experiences should be exposed to trainee-teachers, both those in the distance mode and those in the conventional mode. Simonson, Schlosser and Hanson (2013) indicated that learning experiences are not identical, but various learning experiences can be considered equivalent if they produce the equivalent learning. It is, however, significant to observe that the total contribution of the independent variables to the variance in the dependent variable as shown in Table 2 is 0.750 with an adjusted $\mathrm{R}^{2}$ of 0.747 . This means that the components of instructional quality are able to predict or explain 75 percent of the variance in trainee-teachers' effectiveness. This means, quite apart from the entered dimensions of instructional quality, other components or variables that are not yet considered in the model have a chance of contributing the remaining 25 percent to trainee-teachers' effectiveness.

The finding that instructional quality has a significant impact on trainee-teachers' effectiveness is again consistent with the submission of Koomson et al. (2017), who argued that the competence of a trainee-teacher is largely influenced by school and home environments. Therefore, wellorganised classes concerned with home and school environment may provide a message about the physical fitness of learning setting in order to generate knowledge for learners where learning might be facilitated from both home and school. This may mean that quality of classroom interaction might be hampered due to insufficient teaching resources and poor physical facilities.

This shows that teacher's knowledge, roles, skills, dispositions, and behaviours, all have great influence on effective teaching (Darling-Hammond, 2014). Indeed, teachers who exhibit high level of instructional quality know how to create successful learning environment in classroom. Therefore, an effective teacher must be expert in action system as well as content based pedagogical knowledge, have mastery in the language of instruction, create productive and joyful learning environment, arouse interests among the students in their studies, generating compliant classroom environment for students' needs, bearing strong ethical minds, dedication in profession and intensive caring for students (Ertmer, 2015; Harris \& Sass, 2017). 
Journal of Education and Practice

ISSN 2520-467X (Online)

Vol.4, Issue No.2, pp 1 - 19, 2020

www.carijournals.org

\subsection{CONCLUSIONS AND RECOMMENDATIONS}

\subsection{Conclusions}

From the findings of the study, the following conclusions are drawn. First, the study concluded that pedagogical quality and quality evaluation and quality infrastructure were the dimensions of instructional quality that highly predicted trainee-teacher effectiveness. This is because trainees were able to develop and demonstrate high level of instructional methods that promote learner interactions in various forms as well as delivery of suitable and quality content to learners during their On Centre Teaching Practice (OCTP) at the College of Distance Education, University of Cape Coast.

\subsection{Recommendations}

The findings that emerged from the research question of the study indicated that trainee-teachers ranked the pedagogical and evaluation qualities of the college high. However, those of infrastructure, quality faculty and quality interaction were ranked less. This means that traineeteachers are satisfied with the contents of courses being taught, tutors usage of appropriate teaching learning materials, and their demonstrated professionalism, and competency. Also, they are satisfied with the periodic evaluation of course and trainees professional skills. The study, recommended to management of the CoDE to encourage the course tutors to keep the good work that they are doing with regard to quality evaluation and provision of quality pedagogical skills to trainees. Also, management should provide better infrastructure and technological support services to facilitate students' research report writing and presentation skills.

\section{REFERENCES}

Abderahman, M. A. (2012). The efficiency of a group training programme on increasing awareness towards training needs among day centres' female teachers in Al-Karak province, South of Jordan. European Journal of Social Sciences, 28(4), 452-464.

Abdus-Salam, M. (2015). Quality in teaching and learning in primary public and private schools in Bangladesh. Unpublished master's thesis, Department for Educational Research, Faculty of Educational Sciences, University of Oslo, Oslo.

Ahiatrogah, P., Deku, P., \& Bakari, D. (2008). Effect of study habit on the academic performance of distance education learners of university of cape coast. Cape Coast: UCC Press.

Albemarle, C. P. (2015). A system model for high-quality teaching and learning. Retrieved from https://www2.k12albemarle.org/acps/division/fq1/Pages/How-the-Framework-forQuality-Learning-is-Organized.aspx

Alharbi, E. A. (2017). Educating teachers for diversity: Meeting the challenge. Unpublished doctoral thesis, Cardiff School of Education, Cardiff Metropolitan University, Cardiff.

Ali, M. A. (2000). Supervision for teacher development: An alternative model for Pakistan. International Journal of Educational Development, 20, 177-188.

Anamuah-Menasah, J. (2015, April). Distance education: Our hope for a sustained human capacity development in Ghana. A Keynote Address Given at a National Stakeholders 
Journal of Education and Practice

ISSN 2520-467X (Online)

Vol.4, Issue No.2, pp $1-19,2020$

www.carijournals.org

Forum on the State of Distance Education in Ghana at University of Cape Coast, Cape Coast.

Antoniou, P., \& Kyriakides, L. (2013). A dynamic integrated approach to teacher professional development: Impact and sustainability of the effects on improving teacher behaviour and student outcomes. Teaching and Teacher Education, 29, 1-12.

Azkiyah, S. N. (2013). The effects of two interventions on teaching quality and student outcome: A comparison of education standards and education standards combined with a teacher improvement programme in Indonesia. Groningen: GION.

Badu-Nyarko, S. K. (2010). Isolation and control in distance education: The case of the Ghana student (Electronic version). International Journal of Instructional Technology, 7(3), 1324. Retrieved from http://www.itdl. org/Journal/ Mar_10/Mar_10.pdf

Bird, D. O. (2017). Relationship between teacher effectiveness and student achievement: An investigation of teacher quality. Unpublished doctoral thesis, Department of Educational Administration and Management, College of Education Studies, Ball State University, Muncie, Indiana.

Blazar, D. (2016). Teacher and teaching effects on students' academic performance, attitudes, and behaviours. Unpublished doctoral dissertation, Harvard Graduate School of Education, Harvard University.

Buzdar, A. B. \& Ali, A. (2013). Development of reflective thinking through distance teacher education programmes at AIOU Pakistan. The International Review of Research in Open and Distance Learning, 14(3), 41-56.

Cohen, L. (2008). Research methods in education. New York: Routledge.

College of Distance Education [CoDE] University of Cape Coast [UCC] (2017a). Draft report on students' enrolment statistics by students' records unit. Unpublished report, CoDE, UCC, Cape Coast.

Dankyi, J. K. (2013). Perceived effect of University of Cape Coast distance education on teachers in the basic schools in the Kwahu Municipality. Unpublished master's thesis, Department of Educational Foundations, Faculty of Education, University of Cape Coast, Cape Coast.

Dankyi, L. A. (2016). Study habits of University of Cape Coast distance students. Journal of Counselling, Education and Psychology, 4(2), 75-101.

Darling-Hammond, L. (2014). Teacher quality and student achievement: A review of state policy evidence. Retrieved February 7, 2017, from http:// www.asu.edu/apaa.html

Dillon, C., \& Blanchard, D. (2015). Education for each learner driven distance education. Paper presented at The Second American Symposium on Research in Distance Education, The American Centre for the Study of Distance Education, The Pennsylvania State University, Pennsylvania.

Emmer, E. T., \& Stough, L. M. (2015). Classroom management: A critical part of educational psychology, with implications for teacher education. Educational Psychologist, 49(2), 103112. 
Journal of Education and Practice

ISSN 2520-467X (Online)

Vol.4, Issue No.2, pp $1-19,2020$

www.carijournals.org

Ertmer, P. A. (2015). Teacher pedagogical beliefs: The final frontier in our quest for technology integration? Educational Technology Research and Development, 63(4), 25-39.

Farajollahi, M., Zare, H., Hormozi, M., Sarmadi, M. R., \& Zarifsanaee, N. (2010). Assessment of distance education: A conceptual model for effective distance course facilitation (Electronic version). Turkish Online Journal of Distance Education, 13(2), 632-648. Retrieved May 27, 2017, from www.intechopen.com

Feldman, R. S. (2013). Psychology and your life. New York, NY: McGraw Hill.

Grasha, A. F. (2016). An integrated model of teaching and learning style. In A. F. Grasha (Ed.), Teaching with style (pp. 149-206). San Bernadino, CA: Alliance Publishers.

Grasha, A. F., \& Yangarber-Hicks, N. (2013). Integrating teaching styles and learning styles with instructional technology. College Teaching, 48(1), 21-34.

Hannay, M., \& Newvine, T. (2016). Perceptions of distance learning: A comparison of on-line and traditional learning. MERLOT Journal of Online Learning and Teaching, 12(1), 1-9.

Hanson, M. (2013). Educational administration and organizational behaviour $\left(7^{\text {th }}\right.$ ed.). Boston, MA: Allyn and Bacon.

Harris, D. N., \& Sass, T. R. (2017). Teacher training, teacher quality and student achievement. International Journal of Education Research, 24(2), 34-47.

Harris, D. N., Ingle, W. K., \& Rutledge, S. A. (2014). How teacher evaluation methods matter for accountability: A comparative analysis of teacher effectiveness ratings by principals and teacher value-added measures. American Educational Research Journal, 51(1), 73-112.

Helms-Lorenz, M., Slof, B., Vermue, C. E., \& Canrinus, E. T. (2017). Beginning teachers' selfefficacy and stress and the supposed effects of induction arrangements. New York: Free Press.

Hill, J., \& Hawk, K. (2017). Making a difference in the classroom: Effective teaching practice in Low Deciles, multicultural schools. Retrieved January 21, 2018, from http://www.minedu.govt.nz/index.cfm

Holmberg, B. (2014). Guided didactic conversations in distance education. In D. Sewart, D. Keegan, \& B. Holmberg (Eds.), Distance education: International perspectives (pp. 114122). New York: Routledge.

Jung, I. (2012). Asian learners' perception of quality in distance education and gender differences. Retrieved May 23, 2017, from http://www.irrodl.org/ index.php/irrodl/article/view/1159/2128

Khan, H. K., \& Halai, A. (2014). Exploring reflective dialogue as a strategy for teacher development. In Q. Rashida, \& S. Fauzia (Eds.), Schools and schooling practices in Pakistan: Lessons for policy and practice (pp. 68-86). Karachi: Oxford University Press.

Kizilbash, H. H. (2014). Teaching teacher to teach. In H. Pervez (Ed.). Education and the state: Fifty years of Pakistan (pp. 102-135). London: Oxford University Press.

Koomson, A. K. (2007). Distance education as a strategy for training teachers in Ghana: problems and prospects. Cape Coast: University Press. 
Journal of Education and Practice

ISSN 2520-467X (Online)

Vol.4, Issue No.2, pp $1-19,2020$

www.carijournals.org

Koomson, A. K., Brown, P., Anyagre, P., Ahiatrogah, P., \& Dawson-Brew, F. (2017). Educational psychology. Cape Coast: College of Distance Education, University of Cape Coast.

Kwakyewaa J. D. (2013). Perceived effect of university of cape coast distance education on teachers in the basic schools in of kwahu municipality. Published M.phil thesis, University of Cape Coast.

Kwao, A. (2002). Impact of teacher competence on students' performance. Unpublished master's dissertation, Faculty of Education, University of Cape Coast.

Lee, M. S. C. (2015). Teaching tools, teachers' rules: Scratch in the classroom. Unpublished master's thesis Department of Early Childhood, Tufts University.

Leman, P., Bremner, A., Parke, R. D., \& Gauvain, M. (2012). Developmental psychology. New York: McGraw-Hill.

Mbwesa, J. K. (2014). Students perceived quality of distance education courses as a correlate of learner satisfaction: A case study of the bachelor of education arts programme. Retrieved June 19, 2017, from http://ijsss.red fame.com.

Muijs, D., \& Reynolds, D. (2011). Effective teaching: Evidence and practice (3 ${ }^{\text {rd }}$ ed.). London: SAGE.

Muijs, D., Armstrong, P., \& Chapman, C. (2010). The impact of teach first teachers in schools: Final report. London: The Maximum Impact Project for Teach First.

Nicole, M. (2012). Instructional design and technology. Retrieved from https:// nicolemeredith.wordpress.com/educ-6135/distance-learning-theories equivalency-theory/

Odden, A., Borman, G., \& Fermanich, M. (2004). Assessing teacher, classroom, and school effects, including fiscal effects. Peabody Journal of Education, 79(4), 4-32.

Ogunleye, A. (2013). Quality assurance and quality indicators in open and distance education: context concerns and challenges. International Journal of Educational Research and Technology, 4(2), 49-62.

Owusu-Boateng, W., \& Essel, R. (2011). Combating the challenges in adult learning: The case of KNUST distance students. Journal of Science and Technology, 31(1), 103-113.

Purdy, S. R. (2017). A qualitative study of instructional coaching based on an analysis of interviews from teachers, coaches, and administrators. Unpublished doctoral thesis, Department of Education and Psychology, College of Education Studies, The University of Wisconsin, Milwaukee.

Rahman, F., Jumani, N. B., Akhter, Y., Chisthi, S. H., \& Ajmal, M. (2011). Relationship between training of teachers and effectiveness teaching (Electronic version). International Journal of Business and Social Science, 2(4), 150-160. Retrieved June 23, 2017, from www.ijbssnet.com

Rivkin, S. G., Hanushek, E. A., \& Kain, J. F. (2012). Teachers, schools and academic achievement. Econometrica, 83(2), 417-458.

Rivkin, S. G., Hanushek, E. A., \& Kain, J. F. (2015). Teachers, schools and academic achievement. Unpublished master's thesis, National Bureau of Economic Research, Cambridge, MA. 
Journal of Education and Practice

ISSN 2520-467X (Online)

Vol.4, Issue No.2, pp $1-19,2020$

www.carijournals.org

Shah, M., \& Alam, M. T. (2012). In-service teacher education: Concepts, significance, duration and evaluation. Pakistan Journal of Education, 39(1), 11-29.

Simonson, M. (1999). Equivalency theory and distance education (Electronic version). TechTrends, 43(5), 5-8. Retrieved from http://search.proquest. com/docview/609961547? accountid=14872

Simonson, M., Schlosser, C., \& Hanson, D. (2013). Theory and distance education: A new discussion. The American Journal of Distance Education, 27(3), 12-29.

Walters, E. E. (2002). The effect of availability and utilisation of educational facilities on trainee teacher performance. Unpublished master's thesis, Faculty of Education, University of Cape Coast.

Wang, M. \& Walberg, H. (2012). Teaching and educational effectiveness: Research synthesis and consensus from the field. In K. J. Rehage, H. C. Waxman, \& H. J. Walberg (Eds.), Effective teaching: Current research (pp. 63-80). Berkeley, CA: McCutchan Publishing.

Wanjala, G., \& Wanjala, E. (2017). Level of teachers' efficiency in work performance in public secondary schools in Wajir North District, Kenya. International Journal of Scientific Research and Innovative Technology, 4(4), 23-36.

Wenglinsky, H. (2014). How schools' matter: The link between teacher classroom practices and student academic performance. Retrieved February 13, 2017, from http://www.asu.edu/apaa.html

White, C. J. (2015). Research: A practical guide ( $3^{\text {rd }}$ ed.). Pretoria: Ithuthuko Investments Publishing.

Wilson, S., \& Floden, R. (2013). Creating effective teachers: Concise answers for hard questions. New York: AACTE Publications.

Yai, H., \& Wang, H. (2012). What is the impact of teacher self-efficacy on students' learning outcomes? Hingkueng University-Taichung, Taiwan 3rd WIETE Annual Conference on Engineering and Technology. 